\title{
Potential of Biochar-Anode in a Ceramic-Separator Microbial Fuel Cell (CMFC) with a Laccase-Based Air Cathode
}

\author{
Pimprapa Chaijak $^{1 *}$, Chikashi Sato ${ }^{2}$, Monthon Lertworapreecha ${ }^{3}$, \\ Chontisa Sukkasem ${ }^{4}$, Piyarat Boonsawang ${ }^{5}$, Noris Paucar ${ }^{2}$ \\ ${ }^{1}$ Department of Biotechnology, Faculty of Science, Thaksin University, Thailand \\ ${ }^{2}$ Department of Civil and Environmental Engineering, College of Science and Engineering, \\ Idaho State University, United States \\ ${ }^{3}$ Department of Biology, Faculty of Science, Thaksin University, Thailand \\ ${ }^{4}$ Department of Food Science and Technology, Faculty of Agro and Bio Industry, Thaksin University, Thailand \\ ${ }^{5}$ Department of Industrial Biotechnology, Faculty of Agro-Industry, Prince of Songkla University, Thailand
}

Received: 3 September 2018

Accepted: 21 October 2018

\begin{abstract}
A cost-effective biochar derived from rubber tree sawdust was prepared by low-temperature pyrolysis at $500^{\circ} \mathrm{C}$ for $2 \mathrm{~h}$. The biochar was placed as an anode electrode in the anode chamber of the novel model ceramic-separator microbial fuel cell (CMFC) with a laccase-based air cathode. The rubber wastewater (with $500 \mathrm{mg} / \mathrm{L}$ sulfate and $1000 \mathrm{mg} / \mathrm{L} \mathrm{COD}$ ) was used as an anolyte. Maximal volumetric power density (PD) of $3.26 \pm 0.08 \mu \mathrm{W} / \mathrm{m}^{3}$, maximal volumetric current density of $3.20 \pm 0.07 \mathrm{~mA} / \mathrm{m}^{3}$, and system internal resistance of $1002 \Omega$ were obtained. The post-treatment results showed sulfate removal and COD removal efficiencies of $88.26 \pm 1.29 \%$ and $89.77 \pm 0.45 \%$, respectively. Our work provided a novel model of a low-cost and economically friendly MFC system. Moreover, this work demonstrated a potential route based on sustainable and economical biochar as a bio-anode for wastewater treatment in an MFC.
\end{abstract}

Keywords: csawdust, yeast, rubber wastewater, sulfate, electricity generation

\section{Introduction}

A Microbial fuel cell (MFC) can directly convert the chemical energy in a substrate to electricity by anode reaction. This technology can be used as a wastewater treatment system and can simultaneously

*e-mail: chaijak.pimprapa@gmail.com removal xenobiotics [1]. In the MFC, the proton exchange membrane (PEM) such as Nafion, is a significant factor that affects the cost of the development (reaching 3000 USD per $\mathrm{m}^{2}$ ) and the performance both in xenobiotic removal and electricity production. Therefore, a low-cost and environmentally friendly cation separator is essential [2]. Previous studies have established that ceramics can offer stability, improve power and treatment potential, create a better condition for the exo-electrogenic bacteria 
to reach resource recovery and even remove pathogens from the wastewater [3-4].

Biochar is a carbon-rich material produced from a biomass pyrolysis process in a low-oxygen condition [5]. It is a cost-effective material for several areas such as management and rehabilitation of infertile soil [6-8]. Moreover, a previous study has indicated that the biochar provides a high surface area for exo-electrogenic biofilm to generate electricity with low-cost operation [9].

Natural rubber is the raw material for the broad range of products such as tires, adhesives, and gloves [10]. In the rubber industry, a massive volume of rubber wastewater is discharged. It is usually treated by stabilization pond methods. In this system, the sulfuric acid is added for rubber particles recovery, and it can convert to sulfate under an anaerobic condition that is harmful for human health [11-12]. Moreover, the stabilization pond system requires a vast installation area and emits a green gas [13].

This study aimed at developing the novel model of a low-cost MFC system with laccase-based cathode by using ceramics as a cation separator. The saw dust-biochar was used as an anode in a bio-electricity generation and simultaneous removal of sulfate from rubber wastewater.

\section{Experimental}

To prepare the ceramic chamber, the ceramic clay was used to create a chamber. The external diameter was $12.0 \mathrm{~cm}$, inner diameter was $11.6 \mathrm{~cm}$, thickness was $0.2 \mathrm{~cm}$ and height was $10.0 \mathrm{~cm}$. It was prepared according to Gajda et al. [14]) at $800^{\circ} \mathrm{C}$ for $3 \mathrm{~h}$ in an electrically heated furnace. The ceramic chamber was soaked in deionized water (DI water) overnight before it was used.

To prepare the laccase-based air cathode, the $5.0 \mathrm{~g}$ of sterile weight constant coconut coir was inoculated by $3.5 \mathrm{~mL} \mathrm{7-day-old} \mathrm{yeast} G$. reessii in potato dextrose broth (initial moisture of $70 \%$ ). Then it was incubated at $30^{\circ} \mathrm{C}$ for 7 days to produce an extracellular laccase [15]. To prepare the rubber tree sawdust biochar, it was prepared according to a modified method of previous studies [16-17] at $500^{\circ} \mathrm{C}$ for $2 \mathrm{~h}$ in an electrically heated furnace. The sawdust biochar was sterilized to remove a contaminated bacteria before it was used.

The $10 \mathrm{~cm}^{2}$ of stainless steel mesh was used as an aircathode, and $10 \mathrm{~cm}^{2}$ of sawdust biochar was used as an anode. The electrodes were linked by $1.0 \mathrm{~mm}$ diameter stainless steel wire. The anode chamber was made by $1.5 \mathrm{~L}$ of the glass cylinder. The ceramic chamber was inserted at the top of the anode chamber, and the diagram of the CMFC is shown in Fig. 1. The rubber wastewater $(500 \mathrm{mg} / \mathrm{L}$ sulfate and $1000 \mathrm{mg} / \mathrm{L}$ chemical oxygen demand (COD)) was prepared according to Chaijak et al. [15].

To operate a CMFC, the $0.9 \mathrm{~mL}$ of rubber wastewater was filled into the anode chamber. The

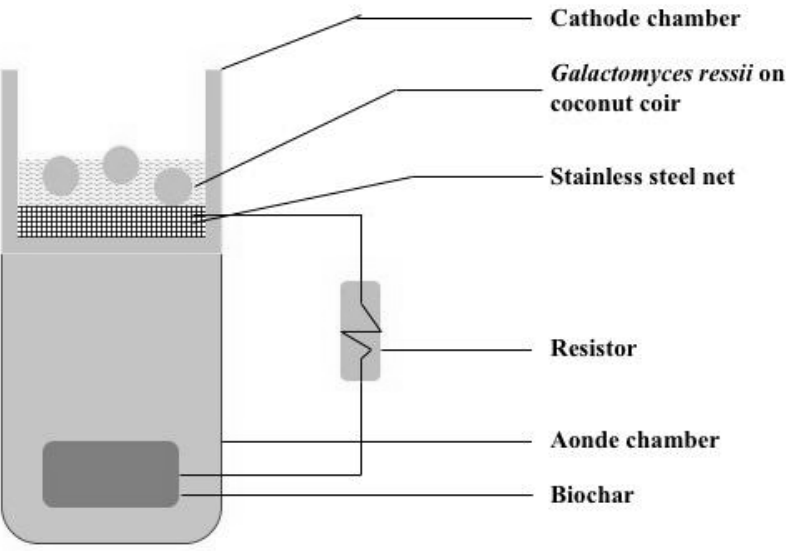

Fig. 1. Diagram of the novel model CMFC with a sawdust biochar anode.

rubber wastewater sludge was collected from the local rubber industry in Southern Thailand. The microbial community was described in Chaijak et al. [15]. The fermented coconut coir with laccase-producing yeast $G$. reessii was planted on the top of a stainless steel mesh electrode to catalyze the reduction reaction on a cathode surface. The open circuit voltage (OCV) was monitored by LabView software (National Instruments, United States) and the data was collected every 10 mins for $24 \mathrm{hrs}$. The closed circuit voltage (CCV) was studied by connecting with seven different resistors $(33,150,270,330,390,1002,2150 \Omega)$. The power density (PD), current density (CD) and the power curve were calculated by the previous study $[2,15]$.

The COD was determined by a Hach 21259-25 COD test kit (Hach, United States). COD removal (\%) was calculated following Eq.1:

$$
\operatorname{COD} \text { removal }(\%)=\left[\left(\mathrm{COD}_{\mathrm{A}}-\mathrm{COD}_{\mathrm{B}}\right) / \mathrm{COD}_{\mathrm{A}}\right] \times 100
$$

...where $\mathrm{COD}_{\mathrm{A}}$ and $\mathrm{COD}_{\mathrm{B}}$ are the initial $\mathrm{COD}$ and final COD. The sulfate concentration was monitored by the turbidimetric method [18]. Sulfate removal (\%) was calculated following Eq. 2, where A and B are the initial and final sulfate concentrations.

$$
\text { Sulfate removal }(\%)=[(\mathrm{A}-\mathrm{B}) / \mathrm{A}] \times 100
$$

\section{Results and Discussion}

Developing cost-effective and highly applicable material for electron acceptance is essential to increasing the electrical production of a bio-electrochemical system [19]. In our study, the sawdust biochar was prepared at $500^{\circ} \mathrm{C}$ for $2 \mathrm{~h}$ and was used as a bio-anode of the novel model CMFC with the low-cost laccase-based air cathode. This study provided the two novel points: 1) it was the first work to apply the CMFC with a biocharanode to treat a rubber wastewater (sulfate and COD removal) and simultaneously generate a bio-electrical 


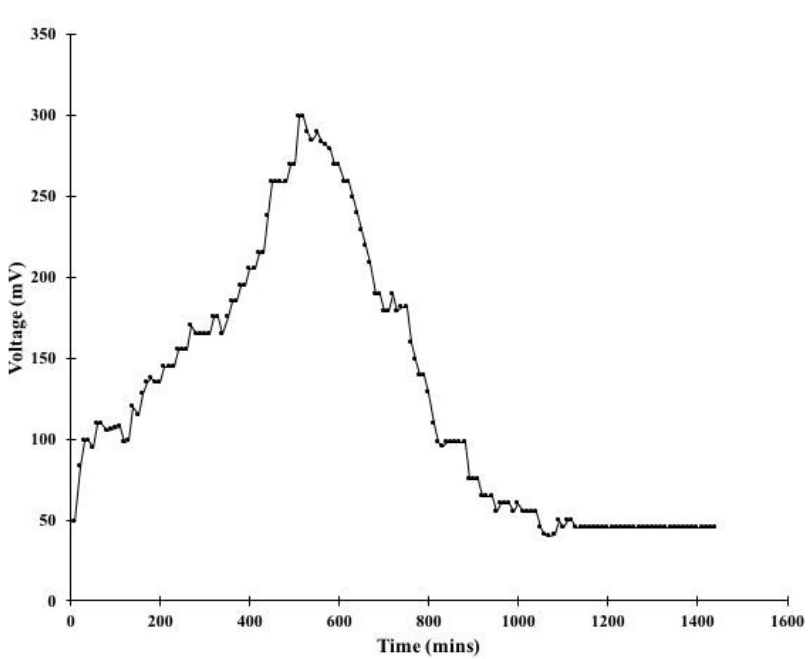

Fig. 2. OCV of the novel model CMFC with a sawdust biochar anode.

energy and 2) it used the whole-cell laccase-producing yeast $G$. reessii planted on cathode electrode of the CMFC to enhance electricity generation instead of highcost platinum. Fig. 2 shows the novel model CMFC with a sawdust biochar-anode producing the maximal OCV at $278.83 \pm 17.32 \mathrm{mV}(\mathrm{N}=3)$ at 500 mins. The maximal $\mathrm{CD}$ of $3.20 \pm 0.07 \mathrm{~mA} / \mathrm{m}^{3}\left(0.32 \pm 0.01 \mu \mathrm{A} / \mathrm{cm}^{2}\right)(\mathrm{N}=3)$ and maximal PD of $3.26 \pm 0.08 \mu \mathrm{W} / \mathrm{m}^{3}(\mathrm{~N}=3)$ were obtained (Table 1). Fig. 3 shows the polarization curve and power density curve of the CMFC with the biochar anode electrode, and this result indicated that the internal resistance of this system is $1002 \Omega$.

The rubber wastewater with the $500 \mathrm{mg} / \mathrm{L}$ sulfate removal and the $1000 \mathrm{mg} / \mathrm{L}$ COD was used as anolyte in an anode chamber to prove the wastewater treatment efficiencies of this CMFC system under $24 \mathrm{~h}$ of operation. The post-treatment data showed the sulfate removal of $88.26 \pm 1.29 \%(\mathrm{~N}=3)$ and the COD of $89.77 \pm 0.45 \%(\mathrm{~N}=3)$. To treat the rubber wastewater, several methods, including MFCs, had previously been used. Jiang et al. used the multi-membrane technology to treat the rubber wastewater. In this system, the

Table 1. Electrochemical properties $(\mathrm{N}=3)$ of the novel model CMFC with a sawdust biochar-anode.

\begin{tabular}{|c|c|c|c|}
\hline Resistance & $\begin{array}{c}\text { Voltage } \\
(\mathrm{mV})\end{array}$ & $\begin{array}{c}\text { Current density } \\
\left(\mathrm{mA} / \mathrm{m}^{3}\right)\end{array}$ & $\begin{array}{c}\text { Power density } \\
\left(\mu \mathrm{W} / \mathrm{m}^{3}\right)\end{array}$ \\
\hline 33 & -- & -- & -- \\
\hline 150 & $0.48 \pm 0.01$ & $3.20 \pm 0.07$ & $1.54 \pm 0.06$ \\
\hline 270 & $0.8 \pm 0.01$ & $2.96 \pm 0.04$ & $2.37 \pm 0.06$ \\
\hline 330 & $0.91 \pm 0.00$ & $2.77 \pm 0.01$ & $2.53 \pm 0.02$ \\
\hline 390 & $1.06 \pm 0.01$ & $2.71 \pm 0.02$ & $2.86 \pm 0.04$ \\
\hline 1002 & $1.81 \pm 0.02$ & $1.80 \pm 0.02$ & $3.26 \pm 0.08$ \\
\hline 2150 & $1.94 \pm 0.05$ & $0.90 \pm 0.02$ & $1.75 \pm 0.08$ \\
\hline
\end{tabular}

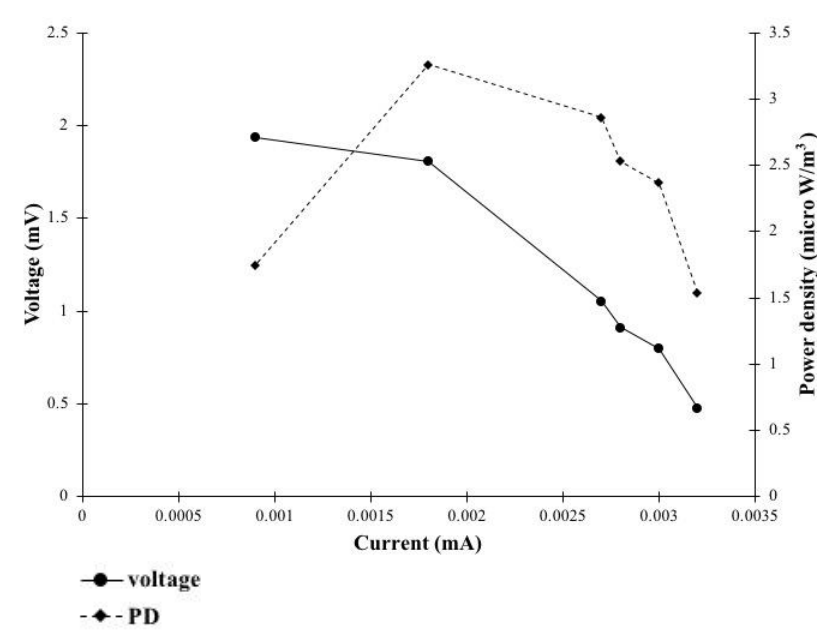

Fig. 3. Polarization and power density curves of the novel model CMFC with a sawdust biochar anode.

rubber wastewater is pretreated by sand filtration and cartridge filtration. Then the filtrated wastewater is forced to pass through the ultrafiltration, nanofiltration and reverse osmosis membrane. The result showed this complex process achieved $99 \%$ of COD removal without generating energy production and sulfate removal. So, this system is limited by its cost of operation, complex process, and outcome [20]. The use of an ozone reactor in rubber wastewater treatment has been reported. In this system, the $22.7 \mathrm{mg} / \mathrm{L}$ of ozone was added into wastewater. The $71.80 \%$ of COD removal efficiency that was obtained [21] was lower than our study by $20.02 \%$ with the addition of an exogenous chemical.

To achieve both wastewater treatment and energy production, MFC technology has been interested. Our previous work used the conventional dual chamber MFC to generate electrical energy. The results indicated that this MFC system can produce the maximal OCV of $250 \mathrm{mV}$, which was lower than this study by $10.34 \%$, while the sulfate removal and COD removal were not determined [15]. Sukkasem and Laehlah used the upflow bio-filter circuit MFC to treat rubber wastewater, but this system still used a commercial anode electrode. Their results showed that $70.00 \%$ of sulfate removal and $80.00 \%$ of COD removal were lower than our study by $20.69 \%$ and $10.88 \%$ [12]. Comparison of the sulfate and COD removal efficiencies of the CMFC system and other microbial fuel cells is shown in Table 2. However, CMFC performances were lower than some other works, reaching $7.09 \%$ to $10.30 \%$ [22-23], that use the commercial electrode as an anode.

To prepare the biochar, many biomass materials have been used. In other hands, the biochar was made from algae prepared at $750^{\circ} \mathrm{C}$ for $2 \mathrm{~h}$. It was used as a bio-anode to produce electrical energy. Their study used the well-known exoelectrogen Shewanella oneidensis. The mineral medium was used as chemical energy for a bacterium to convert to an electric. The result showed the maximal current density of $9.1 \mu \mathrm{A} / \mathrm{cm}^{2}$, 


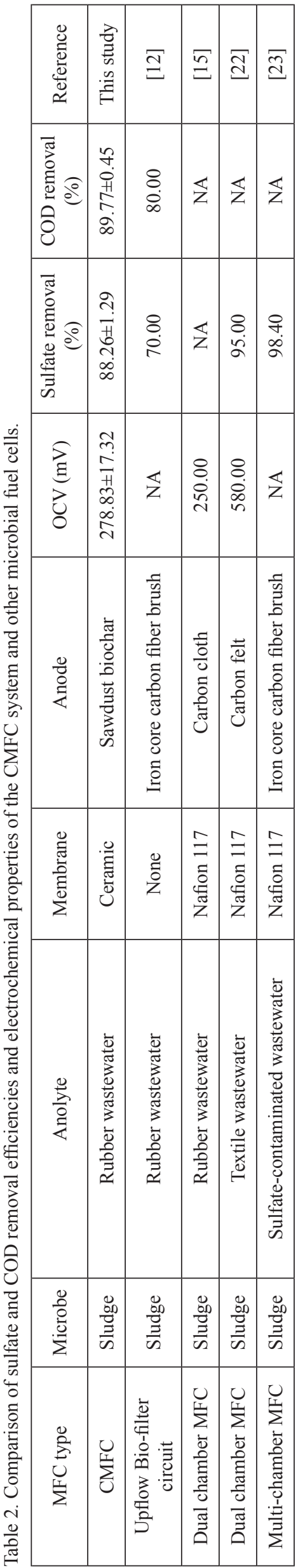

but wastewater treatment efficiency was not provided [19]. Moreover, the previous study was presented using corncob biochar as a bio-cathode electrode in a single-chamber MFC. In their work, the biochar was prepared at $650^{\circ} \mathrm{C}$ for $2 \mathrm{~h}$. The maximal volumetric PD of $458.85 \mathrm{~mW} / \mathrm{m}^{3}$ was achieved while an anode was made from the commercial carbon felt [24]. Thus, our study indicated that the low-temperature prepared sawdust biochar can be used as a low-cost and environmentally friendly anode in the MFC.

\section{Conclusions}

The cost-effective CMFC model is an example of clean technology that uses low-cost biomaterials and biocatalyst (laccase). It enabled the treatment of sulfate and COD in wastewater like other MFC designs without energy consumption. The CMFC with a sawdust biochar anode can generate a volumetric maximal power density with $3.26 \pm 0.08 \mu \mathrm{W} / \mathrm{m}^{3}$. However, the CMFC with a sawdust biochar-anode has to be developed in order to achieve more electrical power outcome in future work.

\section{Acknowledgments}

The authors would like to thank the Department of Civil and Environmental Engineering, College of Science and Engineering, Idaho State University for laboratory support in the CMFC design section and the Science Achievement Scholarship of Thailand to support the student grant.

\section{Conflict of Interest}

The authors declare no conflict of interest.

\section{References}

1. HU J.J., ZHANG Q.G., LEE D.J., NGO H.H. Feasible use of microbial fuel cells for pollution treatment. Renew. Energ., 129, 824, 2018.

2. WU H., FY Y., GUO C.Y., LI Y.B., JIANG N.Z., YIN C.R. Electricity generation and removal performance of a microbial fuel cell using sulfonated poly (ether ether ketone) as proton exchange membrane to treat phenol/ acetone wastewater. Bioresource Technol., 260, 130, 2018.

3. WINFIELD J., GAJDA I., GREENMAN J., LEROULOS I. A review into the use of ceramics in microbial fuel cells. Bioresource Technol., 215, 296, 2016.

4. TREMOULI A., GREENMAN J., LEROPOULOS I. Investigation of ceramic MFC stacks for urine energy extraction. Bioelectrochemistry., 123, 19, 2018.

5. LEHMANN J., JOSEPH S. Biochar for environmental management: an introduction. In Biochar for environmental management science and technology, $1^{\text {st }}$ ed.; LEHMANN J., JOSEPH S., Eds., Taylor and Francis Group: Earthscans, United Kingdom, 1, 12, 2009. 
6. PARK J.H., OK Y.S., KIM S.H., KANG S.W., CHO J.S., HEO J.S., DELAUNE R.D., SEO D.C. Characteristics of biochars derived from fruit tree pruning wastes and their effects on lead adsorption. J. Korean Soc. Appl. Bi., 58 (5), 751, 2015.

7. RIZWAN M., ALI S., QAYYUM M.F., IBRAHIM M., ZIA-UR-REHMAN M., ABBAS T., OK Y.S. Mechanisms of biochar-mediated alleviation of toxicity of trace elements in plants: a critical review. Environ. Sci. Pollut. R., 23 (3), 2230, 2016.

8. EL-NAGGAR A., LEE S.S., AWAD Y.M., YANG X., RYU C., RIZWAN M., RINKLEBE J., TSANG D.C.W., OK Y.S. Influence of soil properties and feedstocks on biochar potential for carbon mineralization and improvement of infertile soils. Geoderma., 332, 100, 2018.

9. AYYAPPAN C.S., BHALAMBAAL V.M., KUMAR S. Effect of biochar on bio-electrochemical dye degradation and energy production. Bioresource Technol., 251, 165, 2018.

10. BOUSQUET J., FLAHAULT A., VANDENPLAS O., AMEILlE J., DURON J.J., PECQUET C., CHEVRIE K., ANNESI-MAESANO I. Natural rubber latex allergy among health care workers: A systematic review of the evidence. J. Allergy Clin. Immun., 118 (2), 447, 2006.

11. CHAIPRAPAT S., SDOODEE S. Effects of wastewater recycling from natural rubber smoked sheet production on economic crops in southern Thailand. Resour. Conserv. Recy., 51 (3), 577, 2007.

12. SUKKASEM C., LAEHLAH S. An economical upflow bio-filter circuit (UBFC): a biocatalyst microbial fuel cell for sulfate-sulfide rich wastewater treatment. Water Res., 1 (1), 168, 2015.

13. HATAMOTO M., NAGAI H., SATO S., TAKAHASHI M., KAWAKAMI S., CHOEISAI P.K., SYUTSUBO S., OHASHI A., YAMAGUCHI T. Rubber and Methane Recovery from Deproteinized Natural Rubber Wastewater by Coagulation Pre-treatment and Anaerobic Treatment. Int. J. Environ. Res., 6 (3), 577, 2012.

14. GAJDA I., STINCHCOMBE A., GREENMAN J., MELHUISH C., LEROPOULOS I. Ceramic MFCs with internal cathode producing sufficient power for practical applications. Int. J. Hydrogen Energ., 40 (42), 14627, 2015.
15. CHAIJAK P., SUKKASEM C., LERTWORAPREECHA M., BOONSAWANG P., WIJASIKA S., SATO C. Enhancing electricity generation using a laccase-based microbial fuel cell with yeast Galactomyces reessii on the cathode. J. Microbiol. Biotechnol., 28 (8), 1360, (2018).

16. LEE Y., EUM P.R.B., RYU C., PARK Y.K., JUNG J.H., HYUN S. Characteristics of biochar produced from slow pyrolysis of Geodae-Uksae 1. Bioresource Technol., 130, 345, 2013.

17. LEE Y., PARK J., RYU C., GANG K.S., YANG W., PARK Y.K., JUNG J., HYUN S. Comparison of biochar properties from biomass residues produced by slow pyrolysis at 500 degrees C. Bioresource Technol., 148, 196, 2013.

18. APHA. Standard Methods for the Examination of Water and Wastewater, 20 $0^{\text {th }}$ ed. In APHA, AWWA, WEF, Washington DC, USA. 1998.

19. WANG Y.S., LI D.B., ZHANG F., TONG Z.H., YU H.Q. Algal biomass derived biochar anode for efficient extracellular electron uptake from Shewanella oneidensis MR-1. Front. Env. Sci. Eng., 12 (4), 1, 2018.

20. JIANG S.K., ZHANG G.M., YAN L., WU Y. Treatment of natural rubber wastewater by membrane technologies for water reuse. Membr. Water Treat., 9 (1), 17, 2018.

21. SARIF S.F.Z.M., ALIAS S.S., RIDWAN F.M., ABIDIN C.Z.A., ALI U.F.M.A., SALIM K.S.K. Disintegration and Solubilisation of Activated Sludge from Rubber Processing Industry by Ozonation. J. Teknol., 80 (1), 1, 2018.

22. MIRAN W., JANG J., NAWAZ M., SHAHZAD A., LEE D.S. Sulfate-reducing mixed communities with the ability to generate bioelectricity and degrade textile diazo dye in microbial fuel cells. J. Hazard Mater., 352, 70, 2018.

23. WANG K., ZHANG S.H., CHEN Z., BAO R.B. Interactive effect of electrode potential on pollutants conversion in denitrifying sulfide removal microbial fuel cells. Chem. Eng. J., 339, 442, 2018.

24. LI M., ZHANG H.G., XIAO T.F., WANG S.D., ZHANG B.P., CHEN D.Y., SU M.H., TANG J.F. Low-cost biochar derived from corncob as oxygen reduction catalyst in air cathode microbial fuel cells. Electrochim. Acta., 283, 780, 2018. 